Olena Ye. Fartushna1, Hanna V. Palahuta², Stanislav K. Yevtushenko33, Rostyslav Yatsynyn4,

Olha G. Selina1, Gabriele M. Tvaskus ${ }^{5}$, Yevhen M. Fartushnyi ${ }^{1}$

'Ukrainian Military Medical Academy, Kyiv, Ukraine

${ }^{2}$ Uzhhorod National University, Regional Clinical Center of Neurosurgery and Neurology,

Uzhhorod, Ukraine

${ }^{3}$ Kharkiv Medical Academy of Postgraduate Education, Kharkiv, Ukraine

${ }^{4}$ Uzhhorod National University, Uzhhorod, Ukraine

${ }^{5}$ Lithuanian University of Health Sciences, Kaunas, Lithuania

\title{
Classic Fabry disease: a clinical case presentation in a resident of Transcarpathia
}

\begin{abstract}
Background. Fabry disease is an inherited X-linked disorder of $\alpha$-galactosidase deficiency that results in the accumulation of globotriaosylceramide and related neutral glycosphingolipids and may cause a wide range of symptoms affecting multiple systems. We aimed to provide a narrative literature overview of Fabry disease, with a clinical case presentation. Materials and methods. We provided a comprehensive clinical, neurological, laboratory, and instrumental analysis of Fabry disease in a young white adult admitted to the Regional Clinical Center of Neurosurgery and Neurology (Uzhhorod, Ukraine). Results and conclusions. We have presented a brief literature overview of the disease, supported with a clinical case of classic Fabry disease in a young white resident of Transcarpathia.
\end{abstract}

Keywords: Fabry disease; classical phenotype; case report; review

\section{Introduction}

Lysosomal storage disorders are a group of heterogeneous diseases caused by compromised enzyme function leading to multiple organ failure [1]. Fabry disease is a rare $\mathrm{X}$-linked deficiency of $\alpha$-galactosidase activity in lysosomes that results in the accumulation of globotriaosylceramide and related neutral glycosphingolipids [2]. This article presents a brief literature overview of the disease with a clinical case of classic Fabry disease in a resident of Transcarpathia (Ukraine).

The purpose of the study: we aimed to provide a narrative literature overview of Fabry disease with a clinical case presentation.

\section{Materials and methods}

We have provided a comprehensive clinical, neurological, laboratory, and instrumental analysis of Fabry disease in a young white adult admitted to the Regional Clinical Center of Neurosurgery and Neurology (Uzhhorod, Ukraine).

\section{Results and discussion}

Lysosomal storage diseases are a group of nearly 60 inherited disorders characterized by inappropriate lipid accumulation in lysosomes due to specific enzyme deficiencies. Gaucher disease was the first of these disorders to be described in 1882 [3], followed by Fabry

( «Міжнародний неврологічний журнал» / «International Neurological Journal» («Meždunarodnyj nevrologičeskij žurnal»), 2021

с Видавець Заславський 0.Ю. / Publisher Zaslavsky 0.Yu., 2021

Для кореспонденції: Фартушна Олена Євгенівна, кандидат медичних наук, магістр медицини, лікар-невролог, старший викладач кафедри авіаційної, морської медицини та психофізіології, Українська військово-медична академія, вул. Іллєнка, 24, м. Київ, 04050, Україна; е-mail: olena.y.fartushna@gmail.com

For correspondence: Olena Fartushna, MD, M.Med.D., PhD, Clinical Neurologist, Senior Lecturer at the Department of Aviation, Marine Medicine and Psychophysiology, Ukrainian Military Medical Academy, Ilyenka st., 24, Kyiv, 04050, Ukraine; e-mail: olena.y.fartushna@gmail.com

Full list of authors information is available at the end of the article. 
disease in 1898 [4-6]. Pompe disease (also known as glycogen storage disease type II) was the first disease to be identified as a lysosomal storage disease in 1963 [7-9]. Most lysosomal storage diseases are characterized by progressive course, often resulting in severe manifestations and early death. Lysosomal storage diseases should be considered in the differential diagnosis of patients with neurologic, muscular, renal degeneration, unexplained hepatomegaly, splenomegaly, cardiomyopathy, or skeletal dysplasias and deformities [10-17].

\section{Definition}

Fabry disease, or Anderson-Fabry disease, is an inherited disorder belonging to the group of lysosomal storage diseases caused by a significant decrease in the activity or absence of $\alpha$-galactosidase A enzyme due to mutations in the GLA gene [1,18]. Deficiency of $\alpha$-galactosidase A leads to the accumulation of globotriaosylceramide and related glycophospholipids in the lysosomes of cells of various organs, including the heart, kidneys, nervous system, and vascular endothelium $[19,20]$. Fabry disease is inherited by a recessive $\mathrm{X}$-linked type. Hemizygous men have a single mutant $\mathrm{X}$ chromosome that they pass on only to their daughters, not sons, which determines the classical phenotype of the disease.

\section{Epidemiology}

The prevalence of the disease in different countries varies widely (from 1 per 117,000 to 1 per 476,000 population) [21]. The International Fabry Disease Genotype-Phenotype Database is constantly updated and contains information on approximately 1,200 patients. According to the Okhmatdyt Clinic, in 2019, twenty patients (18 adults and 2 children) were diagnosed in Ukraine; according to the world statistics, the potential number of patients in Ukraine is 800 .

\section{History}

English dermatologist William Anderson and German dermatologist Johannes Fabry first described the disease in 1898, independently of each other.

In 1898 in England, Fabry described a 13-year-old patient affected by nodular purpura and subsequent albuminuria and he classified this clinical case as angiokeratoma corporis diffusum. That same year in Germany Anderson described a clinical case of a patient aged 39 with angiokeratomas, proteinuria, finger deformity, varicose veins, and lymphedema and suggested this was a case of systemic disorder [22].

In childhood, the disease is manifested itself in pain in the hands and feet, angiokeratomas, hypohidrosis, asthenia; in older age, abdominal pain, lung, kidney, heart damage appear; there is a risk of transient ischemic attacks and stroke [21, 23]. The disease is progressive, accompanied by a decrease in the quality of life and life expectancy. The death of patients usually occurs in the fourth decade of life due to cardiovascular, cerebrovascular complications, or renal failure [24].

\section{Clinical case}

A twenty-four-year-old man presented to his primary care physician complained of the following:

- constant intense burning pain in the hands and feet, which is exacerbated by exercise;

- hypothermia, and overheating;

- episodic tinnitus;

- hearing loss in the right ear;

- episodes of diarrhea;

- dry skin;

- rapid fatigue.

From the age of eight, the patient had attacks of burning intense pain in the feet, which were provoked by hypothermia, overheating, and physical activity. Gradually, over the next two years, the pain became constant, and significantly disrupted the normal functioning of the patient. At the age of 20, the first complaints of burning pain in the hands, provoked by exercise, appeared.

Based on clinical data, a genetic disease was suspected. The results of routine hematological tests were within normal limits. Electromyoneurography showed no pathological changes either. In the plan of diagnostic search, taking into account the patient's complaints, a genetic study was carried out, a molecular diagnosis of the GLA gene was performed, which revealed a mutation of p.560T $>A$ (r.M187K) in the hemizygous state. There were no signs of damage to vital organs and systems characteristic of Fabry disease: proteinuria and signs of chronic kidney disease, heart disease according to electrocardiography and echocardiography, as well as cerebrovascular manifestations.

The patient was diagnosed with a hereditary metabolic disorder from the group of lysosomal storage disorders: Fabry-Anderson disease, X-linked type of inheritance (E75.2). He was referred to the Center for Orphan Diseases for enzyme replacement therapy. The patient receives a lifetime course of fabrazyme at a dose of $1 \mathrm{mg} / \mathrm{kg}$ every 2 weeks.

Family history: parents refused genetic testing.

\section{Conclusions}

Our case presents a late diagnosis of Fabry disease at the age of 20 with the participation of specialist physicians (neurologist, geneticist). In Transcarpathia, selective screening is actively conducted among children and adults at high clinical risk. Early diagnosis of the disease and enzyme replacement therapy significantly improve the state of patients, delaying disease progression and the development of complications as when patients reach 30-40 years of age, they can develop kidney disease, heart disease, and stroke.

\section{References}

1. Vellodi A. Lysosomal storage disorders. Br. J. Haematol. 2005. 128. 413-31. doi: 10.1111/j.1365-2141.2004.05293.x.

2. Meikle P.J., Hopwood J.J., Clague A.E., Carey W.F. Prevalence of lysosomal storage disorders. JAMA. 1999. 281(3). 249-54. 
3. Gaucher P.C.E. De l'épithélioma primitive de la rate. Thèse de Paris. 1882.

4. Anderson W. A case of "angeiokeratoma". Br. J. Dermatol. 1898. 10. 113-17.

5. Fabry J. Ein Beitrag zur Kenntnis der Purpura haemorrhagica nodularis (Purpura papulosa haemorrhagica Hebrae). Arch. Dermatol. Syph. 1898. 43. 187-200

6. Mehta A., Beck M., Linhart A. et al. History of lysosomal storage diseases: an overview. In: Mehta A., Beck M., Sunder-Plassmann G., eds. Fabry disease: perspectives from 5 years of FOS. Oxford: Oxford PharmaGenesis, 2006. Ch. 1. Available from: https:// www.ncbi.nlm.nih.gov/books/NBK11615.

7. Hers H.G. $\alpha$-glucosidase deficiency in generalized glycogen storage disease (Pompe's disease). Biochem. J. 1963. 86. 11-6.

8. Baudhuin P., Hers H.G., Loeb H. An electron microscopic and biochemical study of type II glycogenosis. Lab. Invest. 1964. 13. $1139-52$.

9. Palahuta H.V., Fartushna O.Ye., Oros M.M. et al. Glycogen storage disease type II: a narrative literature review and a case report of late-onset Pompe disease in a young white child. Wiad. Lek. 2021. 74(4). 1032-1036. doi: 10.36740/WLek202104141.

10. Harrison's principles of internal medicine. $19^{h} \mathrm{ed}$. Dennis L. Kasper, Anthony S. Fauci, Stephen L. Hauser, Dan L. Longo, J. Larry Jameson, Joseph Loscalzo, eds. New York: McGraw Hill Education Medical, 2015.

11. Palahuta H.V., Fartushna O.Ye. The role of magnetic resonance imaging of muscles in the differential diagnosis of certain forms and subtypes of limb-girdle muscular dystrophy: case analysis. International Neurological Journal. 2020. 16(8). 43-47. doi: 10.22141/22240713.16.8.2020.221960

12. Fartushna O.Ye., Vinychuk S.M. Tranzytorni ishemichni ataky [Transient Ischemic Attacks]. Kyiv: PH "Avitsena”, 2014. 216 p. (in Ukrainian.)

13. Vinychuk S.M., Fartushna O.Ye. Early rehabilitation after acute ischemic cerebrovascular events. International Neurological Journal. 2016. 8(86). 34-39. (in Ukrainian.) doi: 10.22141/22240713.8 .86 .2016 .90909

14. Fartushna O.Ye., Vinychuk S.M. Detection and removal of vascular risk factors as important area of primary prevention of transient ischemic attack. Ukrainian Medical Journal. 2015. 1(105). 23-27. (in Ukrainian.) Available from: http://nbuv.gov.ua/UJRN/UMCh_2015_1_8.
15. Fartushna O.Ye., Vinychuk S.M. Behavioral risk factors modification as a component of primary prevention of transient ischemic attack and/or stroke. Ukrainian Medical Journal. 2014. 6(104). 4244. (in Ukrainian.)

16. Yevtushenko S.K., Filimonov D.A., Simonyan V.A. et al. Osnovnyye I ovyye faktory riska, sposobstvuyushchiye razvitiyu ishemicheskikh insul'tov u lits molodogo vozrasta [Main and new risk factors promoting the development of ischemic stroke in young persons]. International neurological Journal. 2013. 6(60). 92-100. (in Russian.)

17. Yevtushenko S.K. Geterogennyy ishemicheskiy insul't u detey [Heterogeneous ischemic stroke in children]. International neurological Journal. 2011. 370. 92-100. (in Russian.)

18. Zarate Y.A., Hopkin R.J. Fabry's disease. Lancet. 2008. 372(9647). 1427-35. doi: 10.1016/S0140-6736(08)61589-5.

19. Havndrup O., Christiansen M., Stoevring B., Jensen M., Hoffman-Bang J., Andersen P.S. et al. Fabry disease mimicking hypertrophic cardiomyopathy: genetic screening needed for establishing the diagnosis in women. Eur. J. Heart Fail. 2010. 12(6). 535-40. doi: 10.1093/eurjhf/hfq073.

20. McGorrian C., Constant O., Harper N., O'Donnell C., Codd M., Keelan E. et al. Family-based cardiac screening in relatives of victims of sudden arrhythmic death syndrome. Europace. 2013. 15(7). 1050-8. doi: 10.1093/europace/eus408.

21. Germain D.P. Fabry disease. Orphanet J. Rare Dis. 2010. 5. 30. doi: 10.1186/1750-1172-5-30.

22. Bartolotta C., Filogamo M., Colomba P. et al. FP907 history of Anderson-Fabry disease. Nephrology Dialysis Transplantation. 2015. 30(3). iii379. doi: 10.1093/ndt/gfv186.08.

23. Van Der Tol L., Svarstad E., Ortiz A., Tøndel C., Oliveira J.P., Vogt L. et al. Chronic kidney disease and an uncertain diagnosis of Fabry disease: Approach to a correct diagnosis. Mol. Genet. Metab. 2015. 114. 242-7. doi: 10.1016/j.ymgme.2014.08.007.

24. MacDermot K.D., Holmes A., Miners A.H. Anderson-Fabry disease: clinical manifestations and impact of disease in a cohort of 98 hemizygous males. Journal of Medical Genetics. 2001. 38. 750-760. doi: 10.1136/jmg.38.11.750.

Received 18.05.2021

Revised 31.05.2021 Accepted 08.06.2021

\section{Information about authors}

Olena Y. Fartushna, MD, M.Med.D, PhD, clinical neurologist, Senior Lecturer at the Department of Aviation, Marine Medicine and Psychophysiology, Ukrainian Military Medical Academy, Kyiv, Ukraine; e-mail: olena.y.fartushna@gmail.com; https://orcid.org/0000-0002-4641-0836

Hanna V. Palahuta, PhD student of the Department of Neurology, Neurosurgery and Psychiatry, Uzhhorod National University, Regional Clinical Center of Neurosurgery and Neurology, Uzhhorod, Ukraine; e-mail: hanna.palahuta@uzhnu.edu.ua; contact tel.: +38 (094) 847 0456; https://orcid.org/0000-0001-7348-4390

Stanislav K. Yevtushenko, MD, PhD, Professor, Department of Neurology and Pediatric Neurology, Kharkiv Medical Academy of Postgraduate Education, Kharkiv, Ukraine; e-mail: centerkramatorsk@gmail.com; https://orcid.org/0000-0003-2528-716

Rostyslav Yatsynyn, Uzhhorod National University, Uzhhorod, Ukraine; https://orcid.org/0000-0001-8691-1769

Olha G. Selina, Ukrainian Military Medical Academy, Kyiv, Ukraine; https://orcid.org/0000-0002-8291-5583

Gabriele M. Tvaskus, Lithuanian University of Health Sciences, Kaunas, Lithuania; https://orcid.org/0000-0001-9437-1854

Yevhen M. Fartushnyi, Ukrainian Military Medical Academy, Kyiv, Ukraine; https://orcid.org/0000-0002-5199-5373

Conflicts of interests. Authors declare the absence of any conflicts of interests and their own financial interest that might be construed to influence the results or interpretation of their manuscript.

Information about funding. There was no any role of the funding source.

Authors contribution: Olena Y. Fartushna - article concept and design, data acquisition, interpretation of data, literature search and overview, drafting the article, critical revision of the manuscript for important intellectual content; Hanna V. Palahuta — study concept and design, data acquisition, interpretation of the data, literature search and overview, critical revision of the manuscript for important intellectual content: Stanislav K. Yevtushenko — study concept and design, interpretation of the data, literature overview, critical revision of the manuscript for important intellectual content; Rostyslav Yatsynyn - interpretation of the data, critical revision of the manuscript for important intellectual content; Olha G. Selina — interpretation of the data, literature overview, drafting the article, critical revision of the manuscript for important intellectual content; Gabriele M. Tvaskus — interpretation of the data, drafting the article, critical revision of the manuscript for important intellectual content; Yevhen M. Fartushnyi — interpretation of the data, literature overview, drafting the article, critical revision of the manuscript for important intellectual content. 
Фартушна О.Є.1, Палагута Г.В. ${ }^{2}$, Євтушенко С.К. ${ }^{3}$, Яцинін Р.4, Селіна О.Г.1, Тваскус Г.М.5, Фартушний Є.М. ${ }^{1}$ 'Українська військово-медична акалемія, м. Київ, Україна ${ }^{2}$ Аержавний вищий навчальний зак^аА "УжгороАський національний університет", Обласний клінічний центр нейрохірургії та неврології, м. УжгороА, Україна

ЗХарківська медична акалемія післялипломної освіти, м. Харків, Україна

${ }^{4}$ Аержавний вищий навчальний заклаА "УжгороАський національний університет», м. УжгороА, Україна

${ }^{5}$ Аитовський університет меАичних наук, м. Каунас, Аитва

\section{КАасична форма хвороби Фабрі: презентація клінічного випаАКу}

\section{в жителя Закарпаття}

Резюме. Актуальність. Хвороба Фабрі є спадковою $\mathrm{X}$-зчепленою хворобою дефіциту $\alpha$-галактозидази, що призводить до накопичення глоботріаозилцераміду та пов'язаних із ним нейтральних глікосфінголіпідів й може спричинити широкий спектр клінічних симптомів. Мета дослідження: надати короткий опис літератури щодо хвороби Фабрі, проілюстрований клінічним випадком. Матеріали та методи. Проведено комплексний клінічний, неврологічний, лабора- торний та інструментальний аналіз хвороби Фабрі в молодої білої дорослої людини, яка надійшла до Обласного клінічного центру нейрохірургії та неврології (м. Ужгород, Україна). Результати та висновки. Наведений короткий огляд літератури, підкріплений клінічним випадком класичної форми хвороби Фабрі в молодого білого жителя Закарпаття.

Ключові слова: хвороба Фабрі; класичний фенотип; клінічний випадок; огляд 